\title{
HOW WOMEN HAVE FARED WITH THE RISE OF THE PEOPLE'S REPUBLIC OF CHINA IN GLOBAL SUPPLY CHAIN TRADE
}

Limin Wang, Shireen Kanji, Shikha Jha, and Mieke Meurs

NO. 514

July 2017
ADB ECONOMICS WORKING PAPER SERIES 


\section{ADB Economics Working Paper Series}

\section{How Women Have Fared with the Rise of the People's Republic of China in Global Supply Chain Trade}

Limin Wang, Shireen Kanji, Shikha Jha, and Mieke Meurs

No. 514 | July 2017
Limin Wang (liminwang66@gmail.com) is a consultant at the World Bank, Shireen Kanji

(agapantha.kanji@gmail.com) is a reader in work and organization at the University of Birmingham, Shikha Jha (sjha@adb.org) is principal economist at the Asian Development Bank, and Mieke E. Meurs

(mmeurs@american.edu) is a professor of economics at the American University in Washington, DC.

The paper has benefited from comments and suggestions of peer reviewers, discussants, seminar participants, and other ADB staff. In particular, the authors would like to thank Lena Edlund, Jane Falkingham, Niny Khor, Xin Meng, P. V. Srinivasan, Sofia Shakil, and Joseph E. Zveglich, Jr. They would also like to acknowledge Emmanuel Alano, Pilipinas Quising, James Wang, and Hugo Wu for excellent research assistance. 
(C) (1)

(C) 2017 Asian Development Bank

6 ADB Avenue, Mandaluyong City, 1550 Metro Manila, Philippines

Tel +632632 4444; Fax +6326362444

www.adb.org

Some rights reserved. Published in 2017.

ISSN 2313-6537 (Print), 2313-6545 (e-ISSN)

Publication Stock No. WPS178925-2

DOI: http://dx.doi.org/10.22617/WPS178925-2

The views expressed in this publication are those of the authors and do not necessarily reflect the views and policies of the Asian Development Bank (ADB) or its Board of Governors or the governments they represent.

ADB does not guarantee the accuracy of the data included in this publication and accepts no responsibility for any consequence of their use. The mention of specific companies or products of manufacturers does not imply that they are endorsed or recommended by ADB in preference to others of a similar nature that are not mentioned.

By making any designation of or reference to a particular territory or geographic area, or by using the term "country" in this document, $A D B$ does not intend to make any judgments as to the legal or other status of any territory or area.

This work is available under the Creative Commons Attribution 3.0 IGO license (CC BY 3.0 IGO)

https://creativecommons.org/licenses/by/3.0/igo/. By using the content of this publication, you agree to be bound by the terms of this license. For attribution, translations, adaptations, and permissions, please read the provisions and terms of use at https://www.adb.org/terms-use\#openaccess

This CC license does not apply to non-ADB copyright materials in this publication. If the material is attributed to another source, please contact the copyright owner or publisher of that source for permission to reproduce it. ADB cannot be held liable for any claims that arise as a result of your use of the material.

Please contact pubsmarketing@adb.org if you have questions or comments with respect to content, or if you wish to obtain copyright permission for your intended use that does not fall within these terms, or for permission to use the ADB logo.

Notes:

1. In this publication, "\$” refers to US dollars.

2. ADB recognizes "China" as the People's Republic of China.

3. Corrigenda to ADB publications may be found at http://www.adb.org/publications/corrigenda 


\section{CONTENTS}

TABLES AND FIGURES

ABSTRACT

I. INTRODUCTION

II. TREND ANALYSIS OF GLOBAL SUPPLY CHAIN TRADE AND WOMEN'S EMPLOYMENT

A. The Evolving Position of the People's Republic of China in Global Supply Chain Trade

B. The Evolution of Women's Employment Status

III. PANEL DATA ANALYSIS

A. $\quad$ Model Specification 6

B. Summary of Data 8

C. Key Findings 10

IV. CONCLUDING REMARKS

$\begin{array}{ll}\text { APPENDIXES } & 17\end{array}$

$\begin{array}{ll}\text { REFERENCES } & 21\end{array}$ 


\section{TABLES AND FIGURES}

\section{TABLES}

$1 \quad$ Correlation Matrix

2 Summary of Census Data Variables in the People's Republic of China, 1990, 1995, 2000, and 2010

3 The Impact of Global Supply Chain Trade on Occupation by Gender: Fixed Effect Estimation

4 The Impact of Global Supply Chain Trade on Education by Gender: Fixed Effect Estimation

5 The Impact of Global Supply Chain Trade on Inequality in Occupation and Education: Fixed Effect Estimation

6 Testing the Robustness of Different Measures of Global Supply Chain Trade on Sex Ratio

A3.1 Determinants of the Percentage of Employed Women in Skilled and Management Positions

A3.2 Determinants of the Percentage of Employed Women in Manufacturing Jobs

A3.3 Determinants of the Percentage of Employed Women with a University Degree

A3.4 Determinants of the Percentage of Employed Women with High School Education

\section{FIGURES}

1 Revealed Comparative Advantage Index in the People's Republic of China by Sector, 1995 versus 2013

2 Gross Output Growth by Sector in the People's Republic of China, 1995-2011

3 Female-Male Labor Force Participation Rate in the People's Republic of China by Age Group, 1990-2015

4 Occupational Distribution by Gender in the People's Republic of China in 1982, 1995, 2000, and 2010

5 Trends of Key Trade and Growth Indicators across Provinces in the People's Republic of China, 1990, 1995, 2000, and 2010

6 Women's Welfare Indicators across Provinces in the People's Republic of China, 1990, 1995, 2000, and 2010 


\begin{abstract}
Global supply chain (GSC) trade has been a driving force underlying economic transformation, urbanization, and social change in the People's Republic of China (PRC). Female migrants account for a large share of the labor force in the country's GSC production base. Using province-level panel data, this study employs regression analysis to examine how the country's rapid integration into the supply chain has affected women's welfare outcomes captured by occupational status. The analysis shows mixed results. On the one hand, global integration through trade expansion improved the concentration of men and women equally in professional and skilled occupations and in management positions. On the other hand, female employment in manufacturing for GSC trade increased faster than male employment. This trend decreased in turn the male-female sex ratio among those aged 0-4 years. This finding is consistent with other studies on the PRC that confirm the beneficial effect of a relative rise in women's income in reducing the sex imbalance. Gender-specific policies should support female migrants in moving up the job ladder in GSC trade through higher education and skills training for professional and leadership positions. This should be complemented with incentives for the private sector-the biggest source of employment in the PRC - to promote gender equality by harnessing the advancement in technology and opportunities offered by the rapid growth of GSC trade.
\end{abstract}

Keywords: global supply chain, People's Republic of China, trade, women

JEL codes: F16, J16 


\section{INTRODUCTION}

Integration into trade through the global supply chain (GSC) - the process of breaking down the production process into distinct parts and locating different tasks in different countries-has been a driving force underlying economic transformation, urbanization, and social change in the People's Republic of China (PRC). Chinese migrants have been the backbone of the rapid growth of the country's export industry since the mid-1990s. Indeed, the data show that the spatial distribution of migrant flows followed closely the regional growth of the export and manufacturing sector. In 1990-2010, the top seven destinations of migrant inflows were Guangdong, Zhejiang, Shanghai, Jiangsu, Beijing, Fujian, and Tianjin, all of which are ranked among the top 10 provinces in the PRC in terms of manufacturing and trade (Chan 2013). Together these provinces attracted over 63\% of total migrants in 2010 . By 2012, the migrant population accounted for about $21 \%-25 \%$ of the total urban population and over $38 \%$ of those employed in manufacturing, which contributes over three-quarters of the PRC's GSC trade. Female migrants account for a large share of the labor force in the country's GSC production base, which started in coastal provinces and over time gradually spread to less developed inland provinces.

New empirical evidence from developing country firms shows that internationally engaged firms tend to employ a higher proportion of women workers (Shepherd and Stone 2017). In particular, the cluster of activities related to GSC participation is associated with more intensive use of female labor. How women fared in the course of the PRC's economic transformation has been a largely neglected question in the existing literature. This study intends to fill this knowledge gap and improve policy making that can effectively advance the well-being of Chinese women in GSC trade. This paper follows a regression-based approach to evaluate the impact of GSC trade expansion on women's welfare by using province-level panel data constructed from a combination of four waves of the population census (1982-2010) matched to provincial statistics. We capture welfare by occupation status.

To preview, there are two results that emerged from our empirical analysis: First, global trade expansion improved the labor status of men and women equally in professional and skilled occupations and in managerial positions. In contrast, female employment in manufacturing for GSC trade increased faster than male employment. This finding is consistent with other studies on the PRC in that an expansion of global supply chain network reduces the income gender gap. Gender-specific policies should support female migrants in moving up the job ladder in GSC trade through higher education and skills training for professional and leadership positions, complemented by gender equality incentives for the private sector.

The paper is structured as follows. Section II describes the trends in the PRC's evolving position in GSC trade and the accompanying changes in employment by gender over the past 3 decades. Section III presents the regression analysis of the impact of expanding GSC trade on women's welfare. The concluding section summarizes the key policy messages based on the analysis.

\section{TREND ANALYSIS OF GLOBAL SUPPLY CHAIN TRADE AND WOMEN'S EMPLOYMENT}

\section{A. The Evolving Position of the People's Republic of China in Global Supply Chain Trade}

The PRC has rapidly become the largest manufacturing economy in the course of 3 decades of GSC trade development. By 2012, it had overtaken the three traditional manufacturing giants-the United States, Germany, and Japan-with its share of global manufacturing output rising to 23\% from $4 \%$ in 1980. During this period, these three largest manufacturing countries which had accounted for over $52 \%$ 
of global manufacturing output in the 1980s lost 24 percentage points of global manufacturing output, mainly to the PRC and other Asian economies (Baldwin and Lopez-Gonzalez 2013).

The PRC's integration in GSC trade is not only reflected in the scale of its manufacturing output, its product composition too has evolved significantly over the past 2 decades. During the early phase 1980-2000, its manufacturing in GSCs mainly concentrated on low-technology labor-intensive tradables and export processing, producing goods such as apparel, textiles, and a range of electronic products mainly as assemblers and processers. However, in recent years, rising wages and currency appreciation have reduced the PRC's cost competitiveness. Rising factor costs have resulted in a decline in the PRC's position as a low-technology and low-cost labor-intensive producer in GSC trade. Most multinationals that produce labor-intensive goods, such as textiles and apparel, are already actively diversifying beyond the PRC to reduce costs and mitigate supply-chain risks. Investment data also indicate that the PRC is losing new factory investment to lower-cost locations such as Viet Nam, Bangladesh, and India (Eloot, Huang, and Lehnich 2013).

The second phase of the PRC's economic development since early 2000 saw a fast growth of technology-intensive industries, which accounted for about $33 \%$ of value added as a share of gross domestic product (GDP) by 2012, while low-technology sectors have been facing a steady decline in their overall importance in the national economy. As the PRC rose to join the ranks of middle-income countries, the relative importance of manufacturing in the national economy started to decline, following the widely observed pattern of the manufacturing sector in many high-income countries over the past 2 decades.' By 2011, the growth rate of the country's manufacturing GDP had slowed, indicating it had reached its peak.

Instead, the country successfully upgraded the composition of its manufacturing production. Figure 1 presents the revealed comparative advantage (RCA) index, which is widely used to measure countries' comparative advantage by sector. ${ }^{2}$ The comparison of RCA between 1995 and 2013 shows that the PRC has moved up the production value chain, with the electrical machinery and precision equipment sectors, which are of high-technology intensity, gaining the most. Low-technology sectors, such as leather, pulp, and paper production, have lost RCA. The PRC also reduced exports in sectors that are resource intensive, including animal husbandry as well as coal and coke-related production, although the textile sector remained largely unchanged.

Figure 2 presents the growth rate across subsectors in the PRC between 1995 and 2011. The growth pattern shows that the country is indeed undergoing major structural changes and production upgrading, moving up the value chain. Sectors of high-technology content, such as electrical and optical equipment, chemical products, and machinery, had the highest growth rates, while low-technology sectors had relatively slower growth. The agriculture sector had the lowest growth during this period.

These structural changes in the economy will likely change the demand for skills and bring different types of employment opportunities to reshape the distribution of occupation groups. The key policy question is how the PRC's economic growth, in particular its rising dominance in GSC trade, has impacted women's employment, both in absolute terms and relative to men.

Empirical evidence suggests that the manufacturing sector's relative contribution to a national economy tends to peak when it reaches 20\%-35\% of the country's GDP. By 2012, the PRC's manufacturing sector accounted for roughly 40\% of its GDP.

2 The RCA index is generally calculated as the industry's share of a country's exports divided by its share of world exports (Balassa 1965). An RCA value bigger than 1 indicates that a country has a comparative advantage in specific sectors relative to the world, and less than 1 means that it has a disadvantage in that sector and/or industry. 


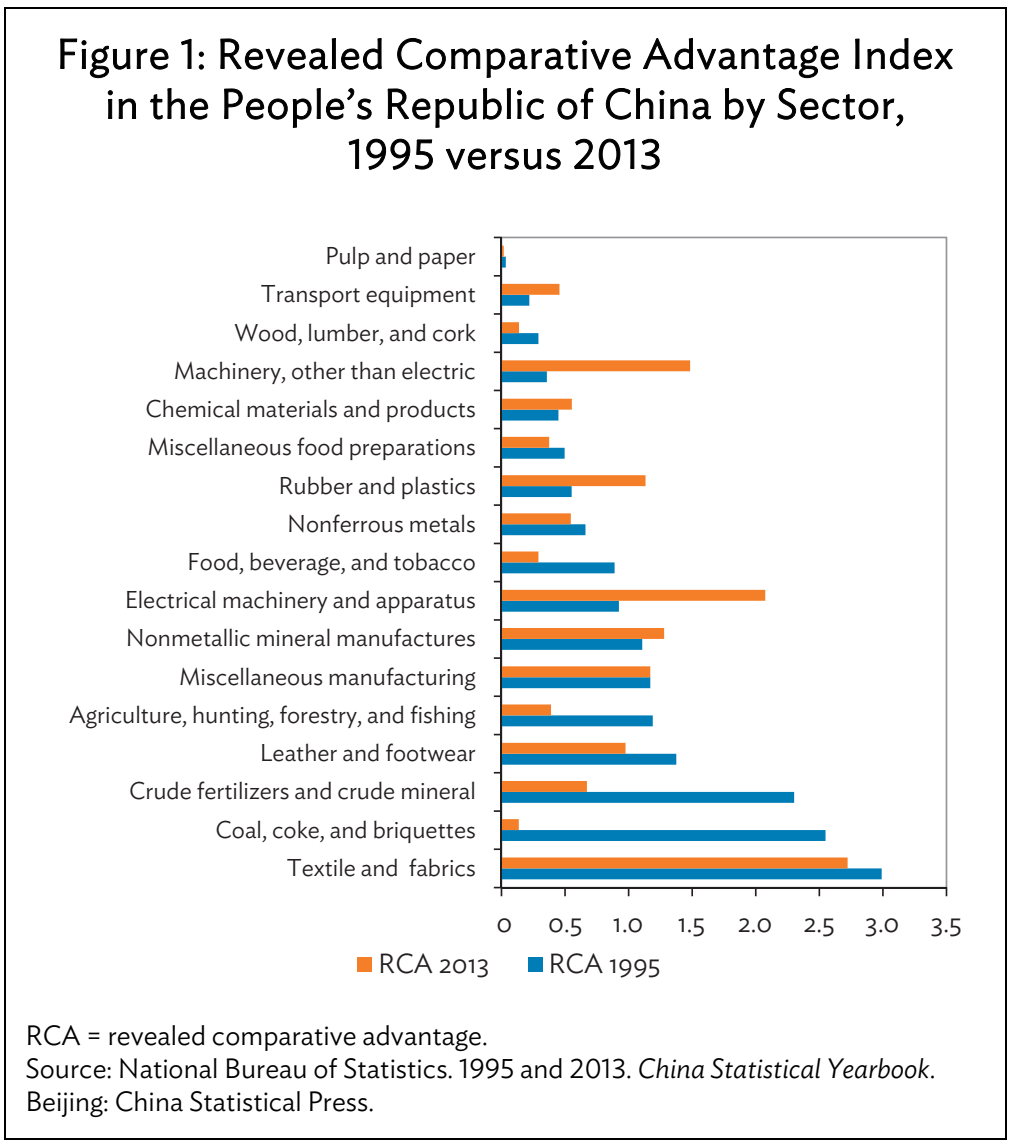

\section{Figure 2: Gross Output Growth by Sector in the People's Republic of China, 1995-2011}

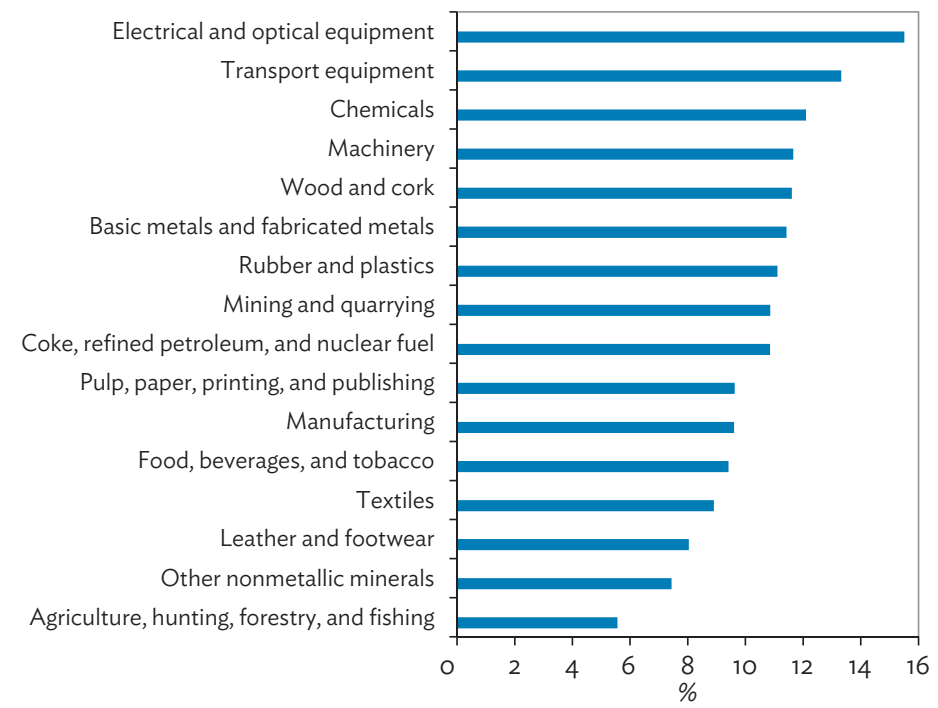

Source: World Bank. World Development Indicators.

http://data.worldbank.org/data-catalog/world-development-indicators (accessed 14 April 2015). 


\section{B. The Evolution of Women's Employment Status}

A critical question is how women's employment evolved during the period the PRC underwent these changes in manufacturing. In assessing the trends in women's employment at the national level, we focus on two indicators: labor force participation and occupation by gender.

Based on official statistics, it is striking that despite rapid growth during this period, the overall female labor force participation rate in the country declined from 79\% in 1990 to only $70 \%$ in 2015. Though the overall male labor force participation rate also declined from $89 \%$ to $84 \%$ during this period, it remained consistently higher than the female one despite elderly women working more than men (Figure 3). However, official data on labor force participation rates could be subject to measurement errors due to difficulties in accounting for the migrant population, or the so-called floating population. The scale of migration across provinces and between rural and urban areas increased from 5\% in 1980 to over $28 \%$ in 2010 , which can bias the measurement of the labor force participation rate if these migrants are not counted in official data.

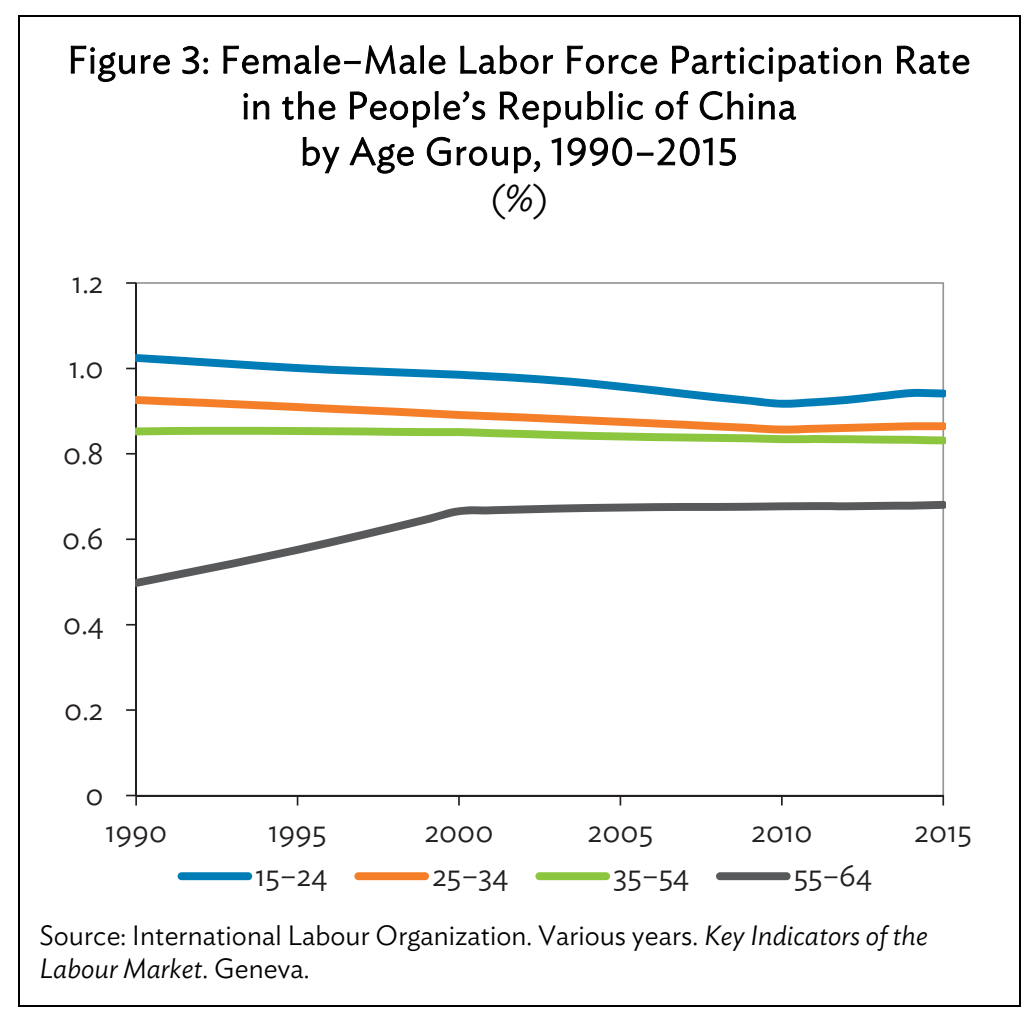

Figure 4 presents the sector and occupational distribution of female employment during 19822010 constructed from the population census data. ${ }^{3}$ The detailed explanations of the five occupations are summarized in Appendix 1. Among the five occupational groups, the services-related, manufacturing-related, and agricultural production-related occupations refer mainly to low-skilled jobs. This classification is also consistent with that used in the 2012 World Bank report on gender equality and development for the purpose of cross-country comparison.

3 The grouping of female employment is constrained by the occupation classifications of the PRC official employment statistics which group sector and occupation together. 


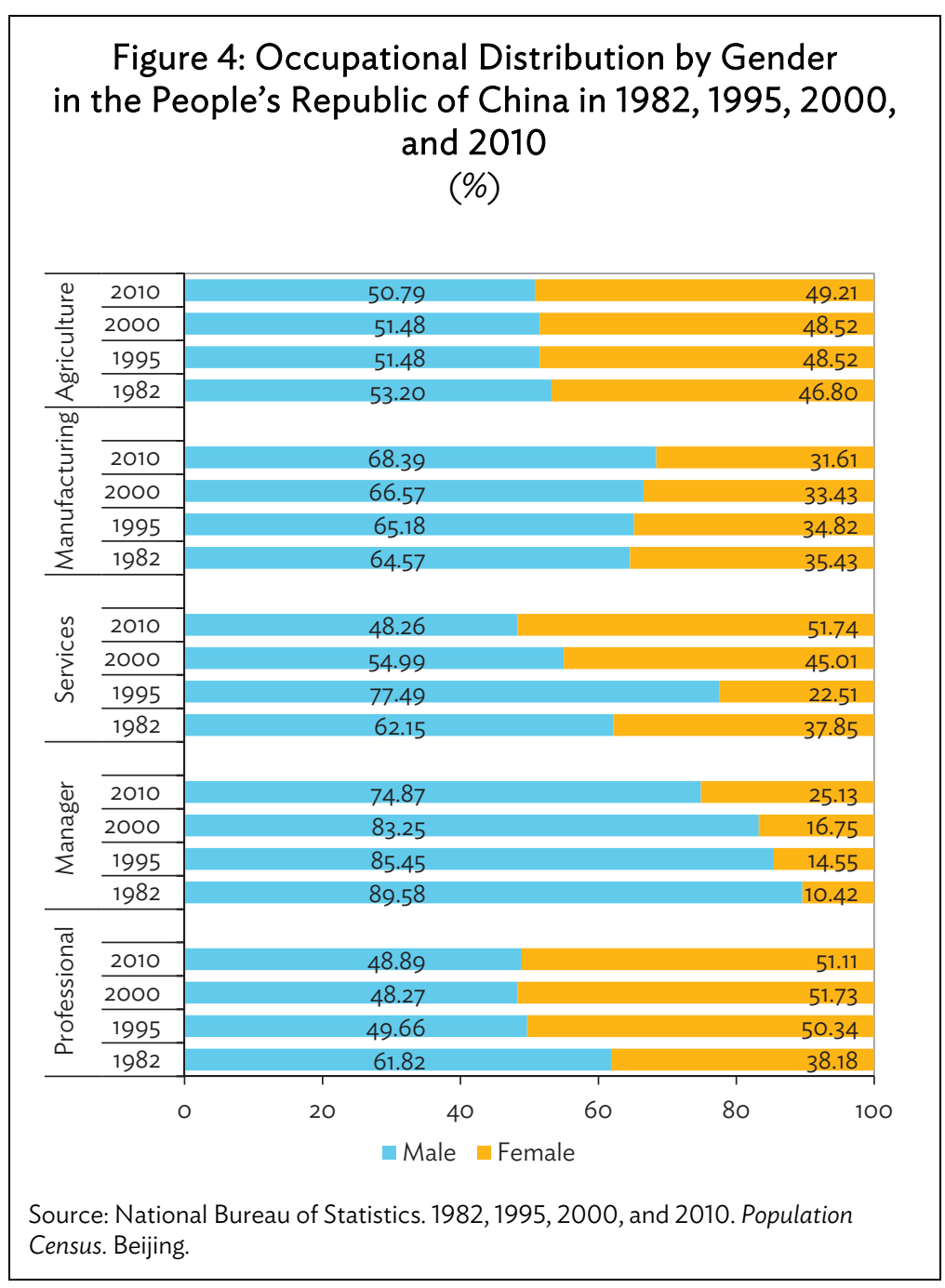

In this section, we focus on two occupational subgroups-professional and skilled occupations and management positions-because they are direct measures of good jobs, which can best capture improvements in women's employment status. The professional and skilled occupational group includes scientific researchers, engineers and technicians, agricultural technical staff, airplane and ship technical staff, hygienic professional and technical personnel, economic business personnel, financial business personnel, professional law personnel, teaching personnel, literature and art staff members, sports staff members, journalism, cultural staff member, and religion-related jobs. The management group consists of leaders of the Central Committee of the Communist Party and of different local organizations, people responsible for government offices and their working organizations and public organizations, and managers in private businesses and enterprises.

From 1982 to 2010, the occupational gender concentration changed markedly. By 2010, women accounted for half of the employees in both agricultural and services-related occupations and about a third of manufacturing occupations, down from 35\% in 1982. Women's occupational status improved significantly, with the largest increase in the proportion of women in professional and management occupations occurring between 1982 and 2010. During this period, the proportion of women increased from $38 \%$ to $51 \%$ in professional jobs and from $10 \%$ to $25 \%$ in managerial occupations. By 2010 , a higher proportion of women than men were in such occupations. 
The PRC's increasing connection with the global economy through GSC trade and foreign direct investment (FDI) has been instrumental in transforming its manufacturing structure and upgrading production. These changes provided new and improved employment opportunities. The impacts of these changes on men and women may depend on gender inequality in education, skills, the functioning of the labor market, migration, and demographic factors such as the dependency ratio. ${ }^{4}$ The foregoing trend analysis presents a positive association between upgrading of the manufacturing structure, as a result of FDI and trade openness, and improvement of women's employment. At the national level, the evidence seems to suggest that women have benefited disproportionally from the economic and structural changes, or at least gained faster access to some of the quality occupations relative to men. These changes can affect private decisions about educational investment for future generations and potentially reshape social norms, leading to a reconfiguration in the forms and extent of gender inequality.

\section{PANEL DATA ANALYSIS}

This section focuses on the estimation of the average impact of integration into GSCs and trade openness on women's welfare using panel regression. The census data that are publicly accessible are only in the form of aggregation at the province level. Therefore, family situations such as marital status and household urban residency (hukou) status cannot be incorporated in the analysis. The provincelevel panel data set was constructed using the four waves of national census data (1990, 1995, 2000, and 2010), matched with other socioeconomic and demographic indicators from the provincial yearbooks (Appendix 2). The final panel data set covers 30 provinces (Chongqing was not included because its province status was granted in 2005) in the 4 years.

The panel data regression is particularly powerful in dealing with the potential estimation bias stemming from time-invariant omitted variables. The unobservable province-specific fixed effects, such as the location advantages or the tradition of entrepreneurship, which are likely to be correlated with the policy variables under study-the development of GSC trade-can be controlled in the panel data regression potentially to eliminate the principal source of estimation bias.

\section{A. Model Specification}

The following model specification is used in the panel data regression:

$$
Y_{\mathrm{it}}=\alpha_{\mathrm{i}}+X_{\mathrm{it}} b+U_{\mathrm{it}}
$$

where $Y_{\text {it }}$ is the women's welfare outcome indicator for province $i$ in year $t ; X_{\text {it }}$ is the vector of covariates including a wide range of demographic variables (population size, dependent ratio, birth rate, population growth rate), measure of GSC trade, sectoral composition, urbanization, average wage level, and government health and education spending; and $\alpha_{i}$ is the province fixed effect. $U_{i t}$ is the error term, that varies over $i$ and $t$. The GSC trade is measured as the ratio of trade to GDP (both current and lagged measures). Since we do not have wage-level information by gender, the average wage level is included in the model as a proxy for labor cost.

4 The dependency ratio is a measure showing the number of dependents, aged 0-14 and over the age of 65 , to the total population aged 15-64. 
The inclusion of government social spending on health and education is particularly important in this study. Global evidence consistently shows that well-designed public policies, rather than market forces, are the driving forces that improve development outcomes, measured by health, education, and equity. In contrast to many countries that have been burdened with large budget deficits combined with slow growth in the aftermath of financial crises, the PRC's fiscal capacity increased over 28 times between the early 1980s and 2010 backed by a sustained annual growth rate of about 7\% over 2 decades. However, the role of government in the provision of social services has been shrinking amid rapid privatization of basic service provision in health and education services. In 2010, government social spending as a share of GDP was about $20 \%$ in the PRC, compared with an average of $44.5 \%$ among members of the Organisation for Economic Co-operation and Development. The PRC's highly decentralized fiscal system further aggravates social disparities. With local governments responsible for funding local services, poor regions were not able to provide quality social services, and poor households were particularly affected due to their limited financial resources to meet the rising costs of health and education services. This is evidently reflected by the strong correlation between income inequality and inequality in social indicators across provinces (Wang 2014).

In the regression analysis, women's welfare status is measured using a wide range of indicators, both in terms of absolute level and in terms of gender inequality measures. The indicators include occupation (share of skilled and management occupation by gender and share of manufacturing occupation by gender) and educational attainment (share of university qualification by gender and share of high school qualification by gender). The inequality measures are the male-female sex ratio of children aged 0-4, female-male ratio of the share of skilled and management occupations, female-male ratio of share of manufacturing occupations, female-male ratio of share of university and high school qualifications.

In estimating the impact of GSC trade on women's welfare indicators, one of the empirical difficulties lies in how to measure a province's connectivity to GSC trade. This is for two reasons. First, measurement errors in trade data can cause either over or underestimation of the true level of trade activities. ${ }^{5}$ As an alternative to trade data, FDI is often used as a measure of GSC trade connectivity. The PRC statistical yearbooks only report FDI flows for individual years, not the cumulative FDI which is a correct measure of GSC trade connectivity. In addition, FDI data tend to display autocorrelation, which further complicates the measure of province-level connectivity to GSC trade in the context of panel data regression analysis.

Table 1: Correlation Matrix

\begin{tabular}{lllll}
\hline & $(1)$ & $(2)$ & $(3)$ & $(4)$ \\
\hline FDI-to-GDP ratio (1) & 1.00 & & & \\
Merchandise trade-to-GDP ratio (2) & 0.48 & 1.00 & & \\
Lag of merchandise trade-to-GDP ratio (3) & 0.68 & 0.60 & 1.00 & \\
Merchandise trade per capita (4) & 0.25 & 0.89 & 0.27 & 1.00 \\
GDP per capita & 0.14 & 0.52 & 0.13 & 0.49 \\
\hline
\end{tabular}

FDI = foreign direct investment, GDP = gross domestic product.

Source: Authors' calculations.

5 It is widely recognized that trade data can be misleading due to reexport activities, and value added data should be used to measure trade which is often not available at the province level. FDI data are also ridden with problems as they are a measure of FDI flows for any given year which often exhibit a negative autocorrelation as a typical time series pattern of investment. 
In the regression analysis, we test the robustness of the results using different measures of GSC trade, including FDI-to-GDP share, trade-to-GDP share, trade per capita, and their lagged variables. Due to the high correlation between trade and FDI data as shown in the correlation matrix in Table 1, the model specification only includes one of them as a measure of GSC trade to mitigate multicollinearity. The full regression results using all four GSC trade measures are reported in Appendix Tables A3.1-A3.4.

\section{B. Summary of Data}

Table 2 summarizes the key variables used in the regression analysis. The dependent variables include measures of women's welfare in terms of level and also gender inequality of these indicators, with the latter expressed as a ratio of female-male outcome indicators.

Table 2: Summary of Census Data Variables in the People's Republic of China, 1990, 1995, 2000, and 2010

\begin{tabular}{|c|c|c|c|c|c|}
\hline Variable & Unit & 1990 & 1995 & 2000 & 2010 \\
\hline \multicolumn{6}{|l|}{ Level Indicator } \\
\hline Female in skilled and management occupation & $\%$ & 7.75 & 8.68 & 8.70 & 10.50 \\
\hline Female in manufacturing production occupation & $\%$ & 14.28 & 12.35 & 11.36 & 14.10 \\
\hline Male in skilled and management occupation & $\%$ & 9.87 & 9.74 & 8.42 & 9.64 \\
\hline Male in manufacturing production occupation & $\%$ & 20.90 & 18.93 & 19.81 & 27.66 \\
\hline Female with university education & $\%$ & 1.88 & 2.20 & 7.38 & 11.29 \\
\hline Female with high school education & $\%$ & 12.01 & 8.92 & 7.49 & 11.83 \\
\hline Male with university education & $\%$ & 3.85 & 3.65 & 8.85 & 10.56 \\
\hline Male with high school education & $\%$ & 17.33 & 11.54 & 10.13 & 6.29 \\
\hline \multicolumn{6}{|l|}{ Inequality Indicator } \\
\hline Male-female sex ratio (aged $0-4$ ) & ratio & 1.09 & 1.16 & 1.18 & 1.17 \\
\hline Female-male in skilled and management occupation & ratio & 0.74 & 0.84 & 0.98 & 1.06 \\
\hline Female-male in manufacturing production occupation & ratio & 0.63 & 0.59 & 0.51 & 0.46 \\
\hline Female-male with university education & ratio & 0.44 & 0.55 & 0.81 & 1.01 \\
\hline Female-male with high school education & ratio & 0.68 & 0.74 & 0.73 & 1.89 \\
\hline \multicolumn{6}{|l|}{ Covariate Measure } \\
\hline FDI & $\$$ million & 104 & 1,218 & 1,305 & 5,817 \\
\hline Trade & $\$$ million & 2,935 & 7,819 & 14,038 & 95,837 \\
\hline FDI-to-GDP ratio & ratio & 0.01 & 0.05 & 0.02 & 0.02 \\
\hline Trade-to-GDP ratio & ratio & 0.17 & 0.25 & 0.23 & 0.30 \\
\hline GDP per capita & $\$$ & 590 & 858 & 1,374 & 5,085 \\
\hline Industry share of GDP & share & 0.40 & 0.42 & 0.42 & 0.49 \\
\hline Ratio of urban-rural income per capita & ratio & 7.47 & 2.78 & 2.82 & 3.02 \\
\hline Education and health expenditure per capita & yuan & 88 & 190 & 325 & 1,763 \\
\hline
\end{tabular}

FDI = foreign direct investment, GDP = gross domestic product.

Source: National Bureau of Statistics. 1990, 1995, 2000, and 2010. Population Census and China Statistical Yearbook. Beijing.

We use two sets of figures to present a summary of these variables over time and across provinces. Figure 5 presents a summary of key indicators capturing GSC trade-related indicators, including trade and FDI, share of industrial sector, and GDP per capita across provinces over time. While these indicators present an upward trend over the past 2 decades, a sharp rise occurred during 19901995, whereas the ratio of FDI and trade to GDP remained constant from 2000 to 2010, suggesting that GSC trade may have reached the local absorptive capacity. 
Figure 5: Trends of Key Trade and Growth Indicators across Provinces in the People's
Republic of China, 1990, 1995, 2000, and 2010

(a) FDI-to-GDP ratio

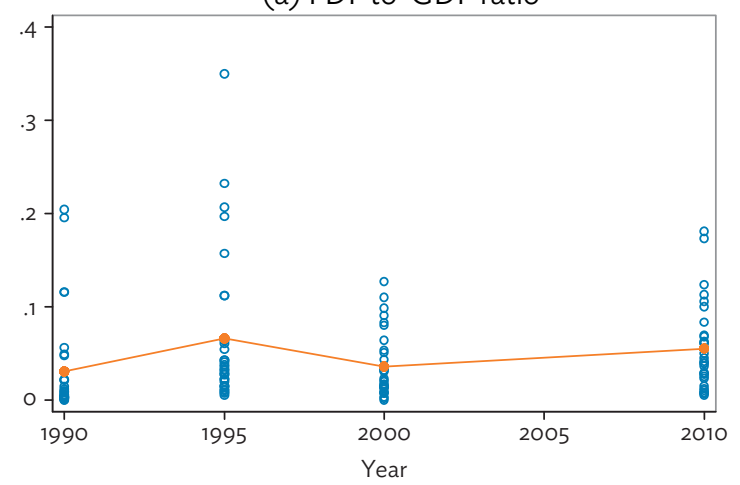

(c) Industry share of GDP

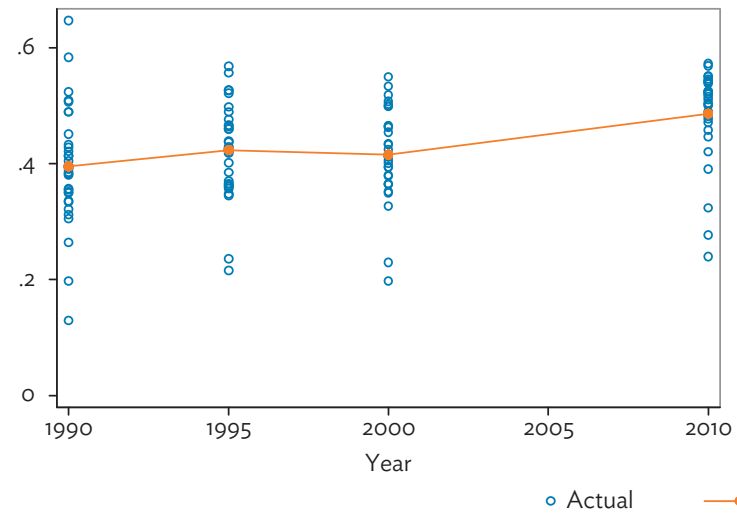

(b) Trade-to-GDP ratio

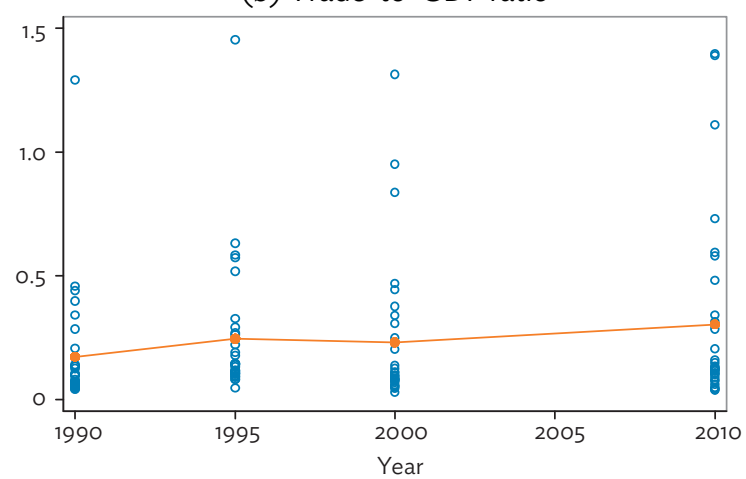

(d) GDP per capita

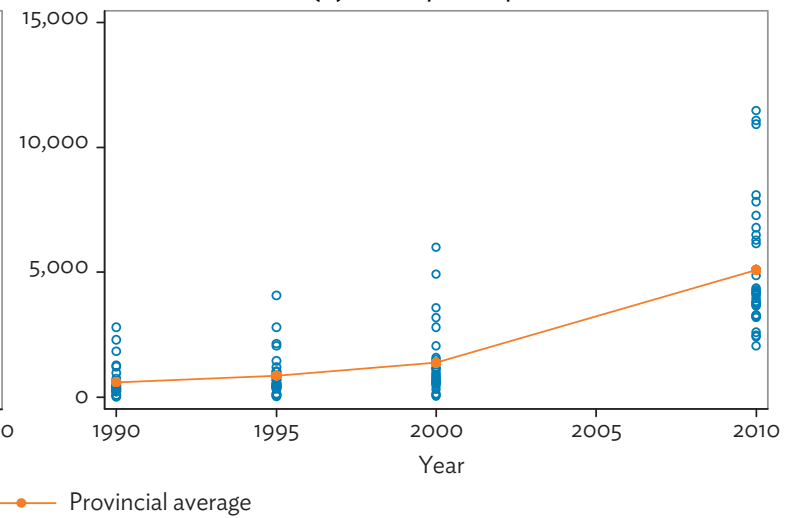

$\mathrm{FDI}=$ foreign direct investment, $\mathrm{GDP}=$ gross domestic product.

Source: These plots are generated from the province panel data constructed using the data from the National Bureau of Statistics. 1990, 1995, 2000, and 2010. Population Census and China Statistical Yearbook. Beijing.

Figure 6 presents a summary of women's welfare indicators under study. The share of female employment in skilled occupations and management positions is the most informative indicator of women's welfare, capturing education, employment, occupation, and empowerment. While there are large variations across provinces, the share of female employees in skilled and management occupations is rising steadily over time. All gender inequality measures expressed as female-male ratios in the outcome indicators, including the share in skilled and management occupation, share of university graduates, and share of high school graduates, show consistent improvement over time in favor of women. However, the male-female sex ratio saw a sharp increase, from 1.08 in 1990 to 1.18 in 2000 , and remained at this level in 2010 (Table 2), indicating a significant worsening of female survival prospects possibly as a result of sex-selective abortions or other forms of overt gender discrimination. 
Figure 6: Women's Welfare Indicators across Provinces in the People's Republic of China, $1990,1995,2000$, and 2010

(a) Female share in skilled and management occupation
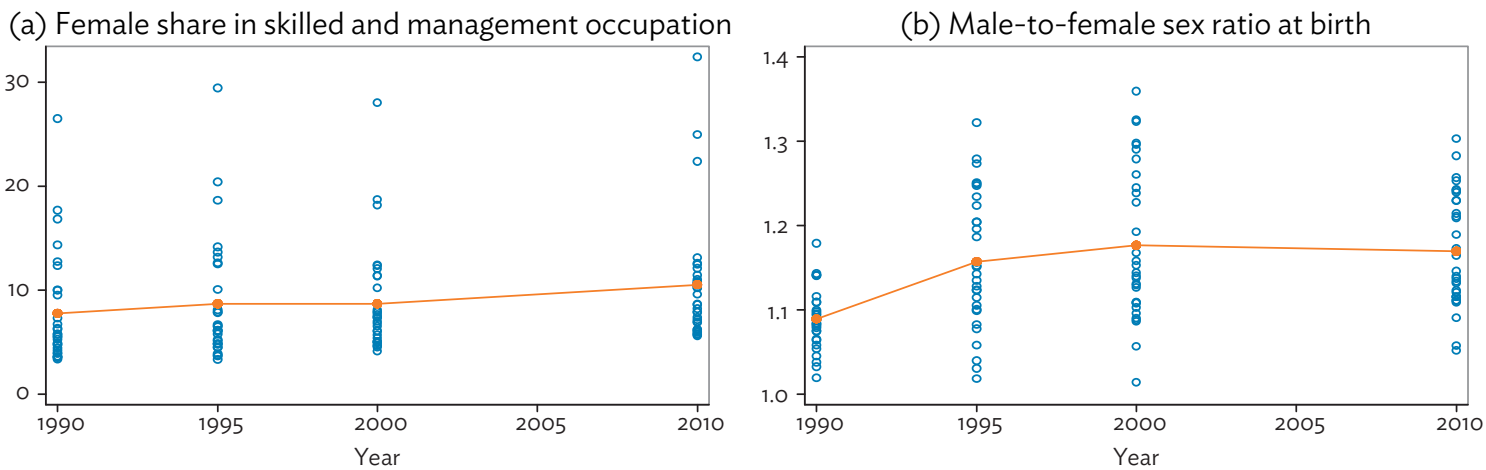

(c) Female share in skilled and management occupation to male share

(d) Ratio of female share in manufacturing job to male share
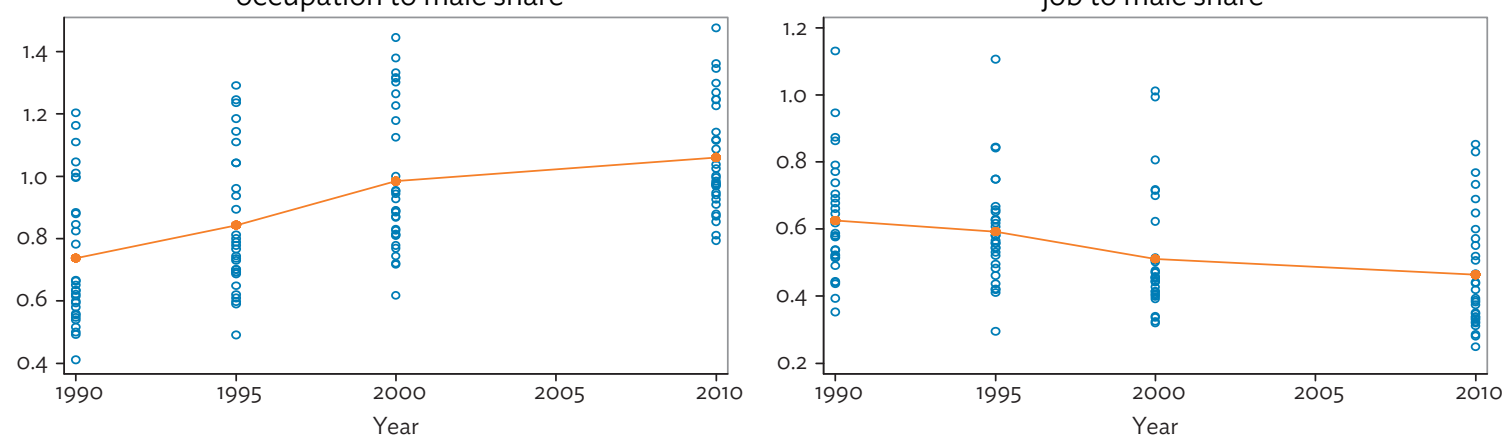

(e) Ratio of female share with university degree to male share

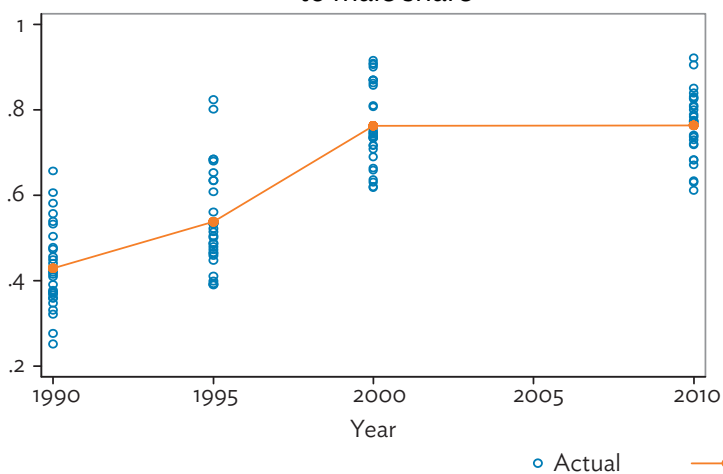

(f) Ratio of female share with high school education to male share

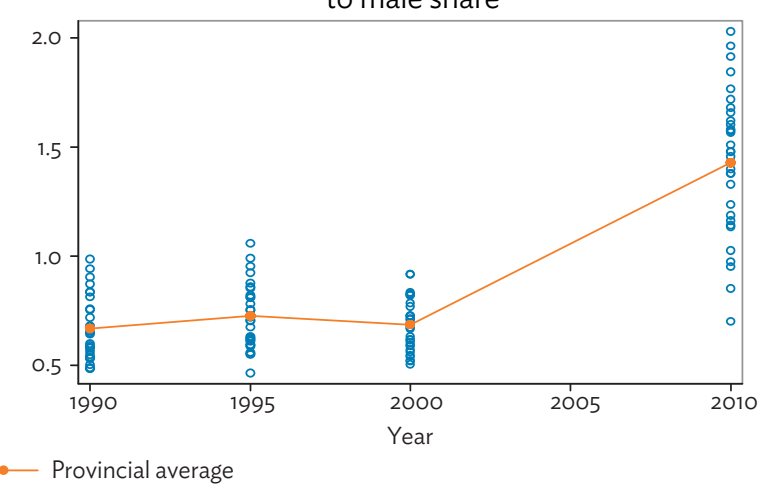

Source: These plots are generated from the province panel data constructed using the data from the National Bureau of Statistics. 1990, 1995, 2000, and 2010. Population Census and China Statistical Yearbook. Beijing.

\section{Key Findings}

We discuss the key findings for the level and the inequality indicators separately. Table 3 summarizes the estimation of the impact of GSC trade on occupation by gender and Table 4 on education by gender. Given that structural change and trade openness through connection to GSC trade often take several years to have an impact on occupation and education outcomes, we use both current and 5-year lagged 
measures of GSC trade in the regression analysis. In occupation, we focus on two broadly defined jobs: (i) quality jobs including skilled and management positions and (ii) manufacturing jobs.

Table 3 shows that after controlling for all key province-level socioeconomic and demographic conditions, the expansion of GSC trade, measured by trade per capita in 5-year lags, increases the concentration of employment in quality jobs for both the female and male labor force, with impacts of similar scale. The estimated impact of GSC trade on the concentration of manufacturing-related occupations is larger for men than for women. However, both current and lagged measures of GSC trade increase the female concentration in manufacturing jobs, whereas only the lagged GSC trade significantly increases the male concentration in manufacturing jobs.

Table 4 summarizes the estimated impact of GSC trade on education qualification by gender. It is surprising to observe that none of the GSC trade measures (current or lagged) has any impact on education. While GDP level has no effect on the male share of university qualification, it has a negative impact on female share of university qualification, which is contrary to conventional expectations. The results show that high government social spending in education and health has a positive impact on both female and male shares of university qualification, but the positive impact is much larger for women than for men ( 0.47 versus 0.12 ).

Table 5 summarizes the estimation results on gender inequality measures in occupation and education, measured by the female-male ratio of the share of skilled and management positions, share of manufacturing occupations, and share of university and high school qualifications. The fixed effect regression results show that the expanding GSC trade has no significant impact on all gender inequality measures, except for the female-male ratio of the share of manufacturing jobs. Holding other factors constant, a $1 \%$ rise in per capita trade increases the female-male ratio of share of manufacturing jobs by 0.06. Although the regression results show no statistically significant impact of GSC trade in favoring the female concentration of skilled and management jobs relative to the male concentration, the official statistics show the female-male ratio of share of quality jobs increased from 0.74 in 1990 to 1.05 in 2010 , indicating that the female labor force had caught up with their male counterparts in securing better occupations.

One important focus of gender inequality is the impact of GSC trade on the male-female sex ratio that has reached alarmingly high levels in the PRC population over the past 2 decades. Given the more complex relationships among GSC trade, the associated changes in occupation structure which differ by gender, migration, and demographic factors, we incorporate the female share of quality jobs and share of university qualification in the model and test the robustness of the results using a range of measures of GSC development. The results are summarized in Table 6. Holding other factors constant, expanding GSC trade (measured by trade per capita) reduces the sex imbalance. Unlike the results for occupation with a lagged effect of GSC trade expansion, the impact of GSC trade on the sex ratio is contemporaneous, and the estimated impact is robust to the inclusion of lagged GSC trade measures (Table 6, column 1 versus column 2).

The estimated effect of GSC expansion is large and significant, with a 1\% increase in trade per capita reducing the sex ratio by 0.03 . Given the average male-female sex ratio (of those aged $0-4$ ) increased from 1.09 in 1990 to 1.17 in 2010, the results suggest that expanding GSC trade can have a sizable impact on reducing the sex imbalance in the PRC. On the other hand, the results also show that the alternative measure of GSC trade using the FDI-GDP ratio (lagged) increases the male-female ratio by 0.38 . Given the issues associated with FDI measures (which measure annual flow rather than the 
stock of FDI and feature possible autocorrelation for given locations), the following discussion focuses more on the trade variable as a measure of GSC trade.

What are the possible explanations for the estimated large beneficial effect of GSC development on female survival prospects? The PRC's exceptionally high male-female sex ratio has attracted the attention of many researchers. Sen $(1990,2003)$ estimated the scale of "missing girls"as a result of the excessive male-female sex ratio at birth - at well over 1 million in 2010, and this was even using conservative estimation methods. Other studies on the sex ratio in the PRC, using a variety of data and methods, all confirm the beneficial income effect, in particular women's income, in reducing the sex imbalance. Using county-level panel data, Qian (2008) found that increasing women's income, holding men's income constant, improves survival rates of girls, whereas increasing men's income, holding women's income constant, reduces survival rates of girls. Wei and Zhang (2011) show that a 1\% increase in per capita income reduces the sex ratio by 3.4 percentage points. Ebenstein (2011) simulates the income effect on the sex balance using three waves of census data (1982, 1990, and 2000) and shows that a subsidy of 1 year of income to families without a son (this can be regarded as implicit income for women) would reduce the number of "missing girls" by $67 \%$.

The estimated impact of income on the sex ratio from our study using four waves of census data is consistent with these previous studies. Piecing together the results from Tables 3 and 4, we are able to trace the underlying causal effect that runs from the expansion of GSC trade to a reduction in the male-female sex ratio. The results in Table 4 show that an increase in GSC trade boosts the femalemale ratio of share of employment in manufacturing, i.e. share of female employment expanded disproportionally faster than that of their male counterparts. This in turn increased female income relative to male income, which improved the survival rates of girls as shown in Table 5.

The development of GSC trade expanded female employment disproportionately because of the concentration of labor-intensive assembling activities, in particular during the early phase of GSC development and integration into the global economy. Women had comparative advantages - such as "nimble fingers" for assembling electronic gadgets and for fine sewing-in employment in provinces with more GSC trade. Such advantages allowed them to earn a higher income relative to men than in other provinces where there existed limited integration with the global economy and low levels of GSC trade, everything else being equal. This finding is consistent with that of Qian (2008) who used householdlevel data to show that women have better employment prospects in tea picking, which boosts their earnings relative to that of men and contributes to higher survival rates of girls. 
Table 3: The Impact of Global Supply Chain Trade on Occupation by Gender: Fixed Effect Estimation

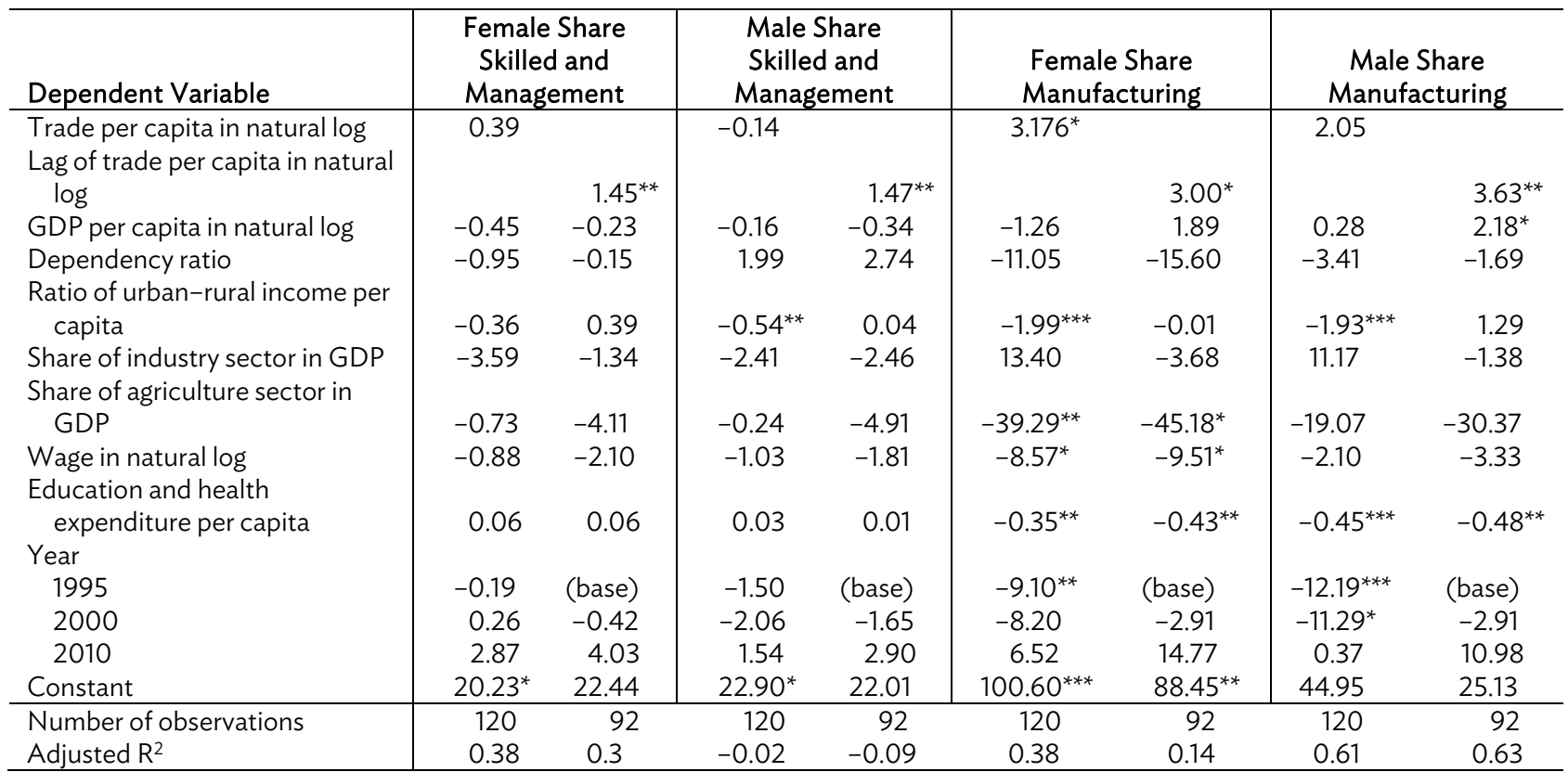

GDP = gross domestic product

Note: ${ }^{*} p<0.05,{ }^{* *} p<0.01,{ }^{* *} p<0.001$.

Source: Authors' calculations.

\section{Table 4: The Impact of Global Supply Chain Trade on Education by Gender:} Fixed Effect Estimation

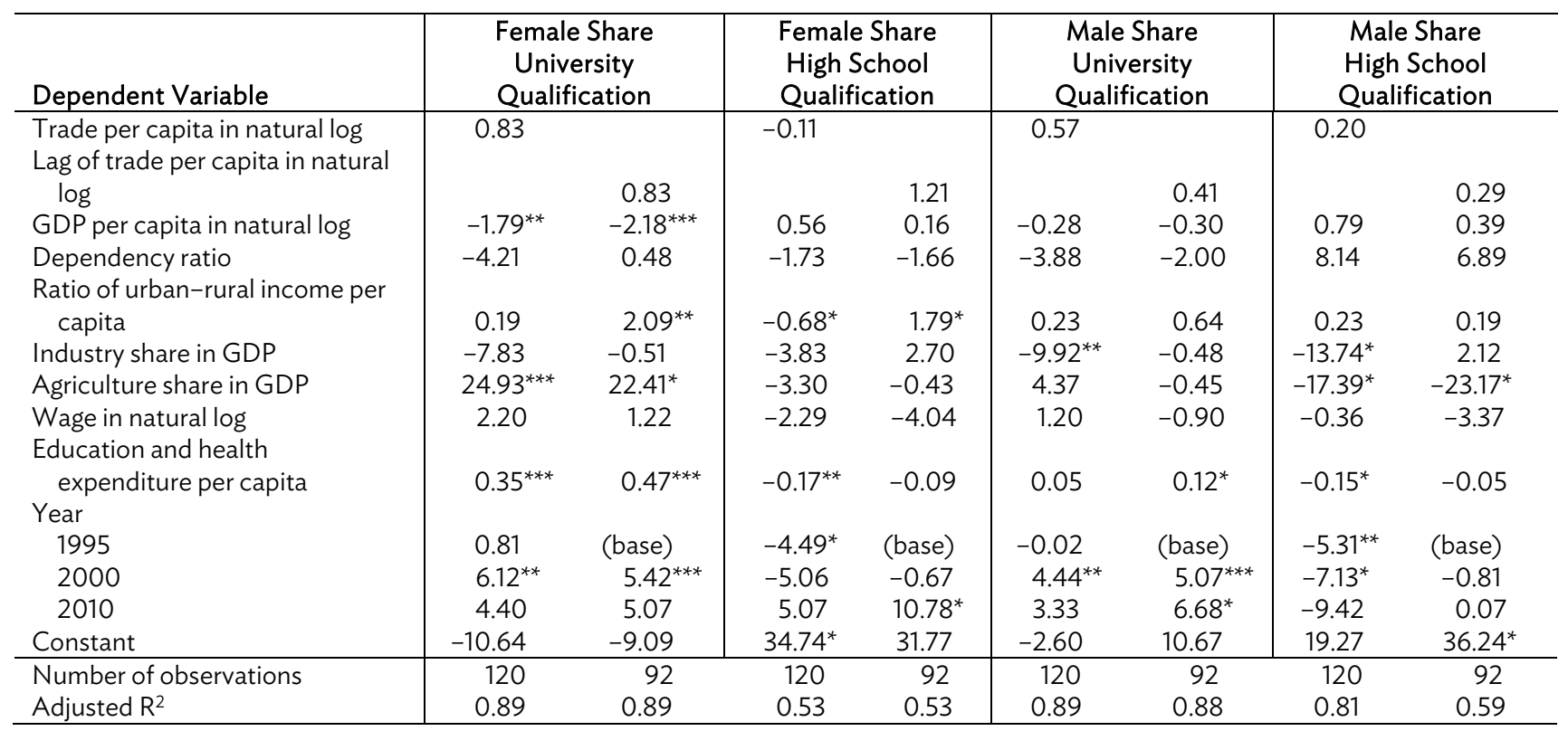

$\mathrm{GDP}=$ gross domestic product.

Note: ${ }^{*} p<0.05,{ }^{* *} p<0.01,{ }^{* * *} p<0.001$

Source: Authors' calculations. 
Table 5: The Impact of Global Supply Chain Trade on Inequality in Occupation and Education: Fixed Effect Estimation

\begin{tabular}{|c|c|c|c|c|c|c|c|c|}
\hline \multirow[b]{2}{*}{ Dependent Variable } & \multicolumn{4}{|c|}{ Ratio (Female-Male Share) } & \multicolumn{4}{|c|}{ Ratio (Female-Male Share) } \\
\hline & $\begin{array}{l}\text { Skille } \\
\text { Manag }\end{array}$ & $\begin{array}{l}\text { and } \\
\text { ment }\end{array}$ & $\begin{array}{r}\text { Manuf } \\
\text { Jo }\end{array}$ & turing & $\begin{array}{l}\text { Univ } \\
\text { Qualit }\end{array}$ & $\begin{array}{l}\text { rsity } \\
\text { :ation }\end{array}$ & $\begin{array}{l}\text { High } \\
\text { Qualif }\end{array}$ & $\begin{array}{l}\text { hool } \\
\text { ation }\end{array}$ \\
\hline Trade per capita in natural log & 0.02 & & $0.06^{*}$ & & -0.01 & & -0.01 & \\
\hline $\log$ & & -0.01 & & 0.02 & & 0.06 & & 0.10 \\
\hline GDP per capita in natural log & 0.00 & 0.03 & -0.03 & 0.03 & -0.02 & $-0.05^{*}$ & 0.09 & 0.08 \\
\hline Dependency ratio & -0.25 & -0.24 & -0.31 & -0.47 & -0.22 & 0.05 & -0.78 & -0.50 \\
\hline $\begin{array}{l}\text { Ratio of urban-rural income per } \\
\text { capita }\end{array}$ & 0.00 & -0.01 & -0.02 & -0.03 & -0.02 & $0.08^{*}$ & -0.04 & 0.22 \\
\hline Industry share in GDP & 0.17 & 0.22 & -0.08 & -0.29 & 0.52 & 0.32 & -0.30 & -0.50 \\
\hline Agriculture share in GDP & -0.14 & -0.10 & $-1.05^{* *}$ & $-1.16^{* *}$ & $1.31^{* * *}$ & $1.33^{* *}$ & 1.77 & 2.14 \\
\hline Wage in natural log & -0.02 & -0.05 & -0.11 & -0.14 & -0.02 & 0.01 & -0.14 & -0.19 \\
\hline $\begin{array}{l}\text { Education and health expenditure } \\
\text { per capita }\end{array}$ & 0.00 & 0.00 & 0.00 & -0.01 & $0.01^{*}$ & $0.01^{*}$ & $-0.03^{* * *}$ & $-0.03^{*}$ \\
\hline Year & & & & & & & & \\
\hline 1995 & 0.07 & (base) & -0.13 & (base) & 0.11 & (base) & 0.09 & (base) \\
\hline 2000 & $0.20^{*}$ & $0.15^{*}$ & $-0.23^{*}$ & $-0.14^{*}$ & $0.44^{* * *}$ & $0.29^{* * *}$ & 0.19 & 0.05 \\
\hline 2010 & 0.24 & 0.24 & -0.18 & -0.01 & $0.68^{* *}$ & $0.48^{*}$ & $2.04^{* *}$ & $1.95^{*}$ \\
\hline Constant & 0.94 & 1.17 & $2.03^{* * *}$ & $2.19^{* *}$ & 0.47 & -0.14 & 1.56 & 0.86 \\
\hline Number of observations & 120 & 92 & 120 & 92 & 120 & 92 & 120 & 92 \\
\hline Adjusted $\mathrm{R}^{2}$ & 0.81 & 0.66 & 0.44 & 0.27 & 0.89 & 0.87 & 0.82 & 0.81 \\
\hline
\end{tabular}

$\mathrm{GDP}=$ gross domestic product.

Note: ${ }^{*} p<0.05,{ }^{* *} p<0.01,{ }^{* *} p<0.001$.

Authors' calculations.

\section{Table 6: Testing the Robustness of Different Measures of Global Supply Chain Trade on Sex Ratio}

\begin{tabular}{|c|c|c|c|c|c|}
\hline \multicolumn{6}{|c|}{ Dependent variable $=$ male-female sex ratio aged $0-4$} \\
\hline & $(1)$ & $(2)$ & (3) & (4) & (5) \\
\hline Trade per capita in natural log & $-0.034^{*}$ & $-0.031^{*}$ & & & \\
\hline Lag of trade per capita in natural log & & 0.009 & -0.001 & & \\
\hline FDI-to-GDP ratio & & & & -0.190 & \\
\hline Lag of FDI-to-GDP ratio & & & & & $0.380^{*}$ \\
\hline Dependency ratio & 0.048 & -0.070 & -0.106 & 0.054 & -0.046 \\
\hline Female share in skilled and management job & 0.000 & -0.002 & -0.001 & 0.000 & -0.001 \\
\hline Female share with university degree & -0.002 & -0.001 & -0.001 & -0.002 & -0.003 \\
\hline GDP per capita in natural log & 0.019 & 0.021 & -0.003 & -0.008 & -0.012 \\
\hline Urban-rural income per capita & $-0.018^{* *}$ & -0.024 & -0.024 & $-0.016^{* *}$ & -0.015 \\
\hline Industry share in GDP & $-0.283^{*}$ & $-0.402^{* *}$ & $-0.312^{*}$ & -0.225 & $-0.306^{*}$ \\
\hline Agriculture share in GDP & $-0.353^{*}$ & -0.238 & -0.153 & -0.301 & -0.237 \\
\hline Wage in natural log & 0.015 & 0.032 & 0.031 & 0.031 & 0.021 \\
\hline Education and health expenditure per capita & 0.001 & 0.000 & 0.000 & 0.000 & 0.002 \\
\hline \multicolumn{6}{|l|}{ Year } \\
\hline 1995 & -0.014 & (base) & (base) & -0.033 & (base) \\
\hline 2000 & -0.012 & -0.022 & -0.003 & -0.029 & -0.002 \\
\hline 2010 & -0.015 & -0.045 & -0.044 & -0.070 & -0.022 \\
\hline Constant & $1.305^{* * *}$ & $1.213^{* * *}$ & $1.221^{* * *}$ & $1.177^{* * *}$ & $1.317^{* * *}$ \\
\hline Number of observations & 120 & 92 & 92 & 120 & 92 \\
\hline Adjusted $\mathrm{R}^{2}$ & 0.437 & -0.247 & -0.337 & 0.401 & -0.217 \\
\hline
\end{tabular}

$\mathrm{FDI}=$ foreign direct investment, GDP = gross domestic product.

Note: ${ }^{*} p<0.05,{ }^{* *} p<0.01,{ }^{* * *} p<0.001$.

Source: Authors' calculations. 


\section{CONCLUDING REMARKS}

While changes in the status of women in development has been the focus of research, existing studies on rapid Chinese growth have ignored how women fared in the occupation concentration in the course of the PRC's economic transformation. Exploiting large changes in labor market conditions due to the PRC's policy experiment in promoting GSC trade (started in coastal provinces and gradually extended to inland regions over the past 3 decades), this study intends to fill this knowledge gap in the well-being of Chinese women. This paper follows a regression-based approach to evaluate the impact of GSC trade expansion on women's welfare in occupational choice by using province-level panel data constructed from a combination of four waves of the population census (1982-2010) matched to provincial statistics.

Our analysis shows that growth in GSC trade increased the concentration of women at par with men in skilled and management jobs. However, the trade expansion had a much larger impact on women's than on men's concentration in manufacturing jobs. The latter effect also helped improve the male-female balance among children up to 4 years of age. The expectation of high female earning potential may reduce the tendency to practice sex-selective abortion and other forms of discrimination against female children. The finding of female comparative advantages in manufacturing employment in locations with large GSC trade is consistent with previous studies.

Improving women's welfare in the face of major structural changes in the PRC, encompassing large-scale rural-urban migration, rapid industrial upgrading and moving up the value chain, and demographic transition requires targeting gender-based policies. Policy makers must recognize the location specificity as well as the complexity of different dimensions of gender inequality which may evolve in contrary directions. Gender-specific policies should target segments of the population such as female migrants who face particularly limited opportunities in moving up the job ladder in the global value chain with higher education and skills training for professional and leadership positions.

The challenge is how to complement gender-based public policies with incentives for the private sector - the biggest source of employment in the PRC - to promote gender equality by harnessing the advancement in technology and opportunities offered by the rapid growth of GSC trade. The relatively successful case of Microsoft's skills training program in the PRC that targeted laid-off workers and migrant women workers with information technology literacy, together with widespread access to online learning technologies, should draw the attention of policy makers to focus on how such initiatives can be fostered and scaled up. 


\title{
APPENDIXES
}

\section{APPENDIX 1: OCCUPATION GROUPINGS}

\author{
Professional and skilled occupation \\ Scientific researchers \\ Engineers and technicians \\ Agricultural technical staff \\ Airplane and ship technical staff \\ Hygienic professional and technical personnel \\ Economic business personnel \\ Financial business personnel \\ Professional personnel of law \\ Teaching personnel \\ Literature and art staff member \\ Sports staff member \\ Journalism, cultural staff member \\ Religious job person \\ Other professional and technical personnel \\ Management
}

Responsible persons of the Central Committee of the Communist Party

Responsible persons of different local organizations

Responsible persons of government offices and their working organizations

Responsible persons of the working organizations of democratic party

Institution unit head

Enterprise director

Services

Commerce, service trade personnel

Purchase and sales personnel

Storehouse personnel

Catering and beverage attendants

Drink, travel, fitness, public place of entertainment attendants

Transport service personnel

Assistant service personnel of medical and health work

Community service and resident life service personnel

Other commerce, service trade personnel

\section{Agriculture}

Crop cultivation production personnel

Forestry production and wild animal and plant protection personnel

Animal husbandry production personnel

Fishery production personnel

Water conservancy facilities management and maintenance personnel

Other water conservancy production personnel

Manufacturing and production related

Survey and mineral exploitation personnel

Metal smelt, rolling personnel

Chemical products production personnel

Machine building processing personnel

Electronic product assembly personnel 
Plant equipment repair personnel

Rig up of electric power, running, overhauling, and power supply personnel

Electronic devices and components, device fabrication, assembly, debugging, and maintenance personnel

Rubber and plastic products production personnel

Textile, knitting, prints and dye personnel

Cutout, sewing, leather, and fur products processing personnel

Grain and oil, food, beverage, and fodder production and processing personnel

Tobacco and goods processing personnel

Medicine production personnel

Timber production and processing personnel

Source: National Bureau of Statistics. 1990-2012. China Statistical Yearbook. Beijing; National Bureau of Statistics. 1982, 1990, 1995, 2000,

2005, and 2010. Population Census. Beijing.

APPENDIX 2: SUMMARY OF THE PEOPLE'S REPUBLIC OF CHINA DATA SOURCES

\begin{tabular}{l|l}
\hline Source & \multicolumn{1}{c}{ Year } \\
\hline Population census & $1982,1990,1995$ (1\%pop), 2000, 2005 (1\%pop), and 2010 (1\%pop) \\
\hline Provincial statistical yearbooks & $1990-2012$ \\
\hline Labor statistics & $1990-2010$ \\
\hline Trade data & World Input-Output Database (WIOD) \\
\hline
\end{tabular}

Note: The population censuses for the following years were carried out for 1\% of the population: 1995, 2005, and 2010.

Source: Authors' compilation. 


\section{APPENDIX 3: REGRESSION RESULTS}

Supplementary regressions: Comparison of five ways of measuring global supply chain (GSC) trade: (1) trade per capita in natural log, (2) trade-to-GDP ratio, (3) lag of trade per capita, (4) FDI-to-GDP ratio, and (5) lag of FDI-to-GDP ratio.

The following tables show results for four different dependent variables:

\section{Table A3.1: Determinants of the Percentage of Employed Women in Skilled and Management Positions}

Dependent variable $=$ Share of females in skilled and management occupations

\begin{tabular}{|c|c|c|c|c|c|}
\hline Explanatory Variables & (1) & $(2)$ & (3) & (4) & $(5)$ \\
\hline Trade per capita in natural log & 0.377 & & & & \\
\hline Trade-to-GDP ratio & & 2.249 & & & \\
\hline Lag of trade per capita in natural log & & & $7.713^{* * *}$ & & \\
\hline FDI-to-GDP ratio & & & & -0.431 & \\
\hline Lag of FDI-to-GDP ratio & & & & & 2.430 \\
\hline GDP per capita in natural log & -0.440 & 0.028 & -0.009 & -0.145 & -0.194 \\
\hline Ratio of urban-rural income per capita & $-0.360^{*}$ & $-0.352^{*}$ & 0.186 & $-0.371^{*}$ & 0.436 \\
\hline Industry share in GDP & -3.592 & -1.894 & 3.918 & -4.428 & 0.690 \\
\hline Agriculture share in GDP & -0.862 & -0.669 & -1.205 & -1.462 & 0.812 \\
\hline Wage in natural log & -0.904 & -1.250 & $-3.693^{*}$ & -0.851 & -2.691 \\
\hline Education and health expenditure per capita & 0.066 & 0.038 & 0.066 & 0.071 & 0.104 \\
\hline \multicolumn{6}{|l|}{ Year } \\
\hline 1995 & -0.162 & 0.107 & (base) & -0.032 & (base) \\
\hline 2000 & 0.354 & 0.744 & 1.164 & 0.347 & 1.282 \\
\hline 2010 & 3.073 & 4.134 & $8.193^{* *}$ & 3.141 & $6.577^{*}$ \\
\hline Constant & $19.952^{*}$ & $20.017^{*}$ & $35.775^{* *}$ & 19.776 & $30.112^{*}$ \\
\hline Number of observations & 120 & 120 & 92 & 120 & 92 \\
\hline Adjusted $\mathrm{R}^{2}$ & 0.388 & 0.409 & 0.344 & 0.383 & 0.182 \\
\hline
\end{tabular}

$\mathrm{FDI}=$ foreign direct investment, $\mathrm{GDP}=$ gross domestic product

Note: ${ }^{*} p<0.05,{ }^{* *} p<0.01,{ }^{* * *} p<0.001$.

Source: Author's calculations.

Table A3.2: Determinants of the Percentage of Employed Women in Manufacturing Jobs

\begin{tabular}{|c|c|c|c|c|c|}
\hline Explanatory Variables & (1) & (2) & (3) & (4) & (5) \\
\hline Trade per capita in natural log & $3.008^{*}$ & & & & \\
\hline Trade-to-GDP ratio & & 5.736 & & & \\
\hline Lag of trade per capita in natural log & & & $16.175^{*}$ & & \\
\hline FDI-to-GDP ratio & & & & -27.224 & \\
\hline Lag of FDI-to-GDP ratio & & & & & 34.254 \\
\hline GDP per capita in natural log & -1.168 & 1.618 & $2.308^{*}$ & 1.278 & 1.521 \\
\hline Ratio of urban-rural income per capita & $-2.001^{* * *}$ & $-2.047^{* * *}$ & -0.231 & $-2.065^{* * *}$ & 0.629 \\
\hline Industry share in GDP & 13.400 & 13.279 & 6.417 & 5.798 & 0.314 \\
\hline Agriculture share in GDP & $-40.801^{* *}$ & $-43.434^{* *}$ & $-44.271^{*}$ & $-47.056^{* *}$ & $-48.255^{*}$ \\
\hline Wage in natural log & $-8.826^{* *}$ & $-9.631^{* *}$ & $-13.664^{* *}$ & -6.270 & $-12.128^{* *}$ \\
\hline Education and health expenditure per capita & $-0.329^{* *}$ & $-0.366^{* *}$ & $-0.386^{* *}$ & $-0.323^{* *}$ & -0.262 \\
\hline \multicolumn{6}{|l|}{ Year } \\
\hline 1995 & $-8.811^{*}$ & $-7.337^{*}$ & (base) & $-8.574^{*}$ & (base) \\
\hline 2000 & -7.046 & -5.850 & 1.622 & -9.528 & 0.688 \\
\hline 2010 & 8.837 & 12.492 & $26.834^{* *}$ & 3.553 & $23.233^{* *}$ \\
\hline Constant & $97.370^{* * *}$ & $98.114^{* * *}$ & $116.401^{* * *}$ & $80.426^{* *}$ & $112.099^{* *}$ \\
\hline Number of observations & 120 & 120 & 92 & 120 & 92 \\
\hline Adjusted $\mathrm{R}^{2}$ & 0.381 & 0.355 & 0.156 & 0.357 & 0.110 \\
\hline
\end{tabular}

$\mathrm{FDI}=$ foreign direct investment, GDP = gross domestic product.

Note: ${ }^{*}<<0.05,{ }^{* *} p<0.01,{ }^{* *} p<0.001$.

Source: Author's calculations. 
Table A3.3: Determinants of the Percentage of Employed Women with a University Degree

\begin{tabular}{|c|c|c|c|c|c|}
\hline \multicolumn{6}{|c|}{ Dependent variable $=$ Share of females with university qualification } \\
\hline Explanatory Variables & (1) & $(2)$ & $(3)$ & $(4)$ & (5) \\
\hline Trade per capita in natural log & 0.77 & & & & \\
\hline Trade-to-GDP ratio & & $5.560^{* * *}$ & & & \\
\hline Lag of trade per capita in natural log & & & $5.980^{*}$ & & \\
\hline FDI-to-GDP ratio & & & & 5.401 & \\
\hline Lag of FDI-to-GDP ratio & & & & & $16.509^{*}$ \\
\hline GDP per capita in natural log & $-1.758^{* *}$ & -0.727 & $-2.027^{* * *}$ & $-1.179^{* *}$ & $-2.370^{* * *}$ \\
\hline Ratio of urban-rural income per capita & 0.183 & 0.206 & $1.924^{* *}$ & 0.153 & $2.286^{* * *}$ \\
\hline Industry share in GDP & -7.825 & -3.277 & 3.201 & -9.291 & 1.032 \\
\hline Agriculture share in GDP & $24.350^{* * *}$ & $25.070^{* * *}$ & $23.715^{* *}$ & $23.505^{* *}$ & $21.159^{*}$ \\
\hline Wage in natural log & 2.100 & 1.238 & 0.129 & 1.644 & 0.622 \\
\hline Education and health expenditure per capita & $0.355^{* * *}$ & $0.284^{* * *}$ & $0.465^{* * *}$ & $0.376^{* * *}$ & $0.516^{* * *}$ \\
\hline \multicolumn{6}{|l|}{ Year } \\
\hline 1995 & 0.922 & 1.525 & (base) & 1.401 & (base) \\
\hline 2000 & $6.560^{* *}$ & $7.508^{* * *}$ & $6.242^{* * *}$ & $7.186^{* *}$ & $5.741^{* * *}$ \\
\hline 2010 & 5.281 & 7.831 & $7.651^{*}$ & 6.962 & 6.292 \\
\hline Constant & -11.872 & -11.756 & -0.179 & -8.125 & -0.771 \\
\hline Number of observations & 120 & 120 & 92 & 120 & 92 \\
\hline Adjusted $\mathrm{R}^{2}$ & 0.890 & 0.903 & 0.893 & 0.888 & 0.892 \\
\hline
\end{tabular}

$\mathrm{FDI}=$ foreign direct investment, $\mathrm{GDP}=$ gross domestic product.

Note: ${ }^{*} p<0.05,{ }^{* *} p<0.01,{ }^{* * *} p<0.001$.

Source: Author's calculations.

Table A3.4: Determinants of the Percentage of Employed Women with High School Education

\begin{tabular}{|c|c|c|c|c|c|}
\hline \multicolumn{6}{|c|}{ Dependent variable $=$ Share of females with high school education } \\
\hline Explanatory Variables & (1) & $(2)$ & (3) & (4) & $(5)$ \\
\hline Trade per capita in natural log & -0.133 & & & & \\
\hline Trade-to-GDP ratio & & 1.187 & & & \\
\hline Lag of trade per capita in natural log & & & 2.410 & & \\
\hline FDI-to-GDP ratio & & & & 0.535 & \\
\hline Lag of FDI-to-GDP ratio & & & & & -7.525 \\
\hline GDP per capita in natural log & 0.569 & 0.558 & 0.254 & 0.464 & 0.311 \\
\hline Ratio of urban-rural income per capita & $-0.684^{*}$ & $-0.670^{*}$ & $1.757^{*}$ & $-0.680^{*}$ & $1.740^{*}$ \\
\hline Industry share in GDP & -3.830 & -2.212 & 5.277 & -3.520 & 4.080 \\
\hline Agriculture share in GDP & -3.539 & -2.932 & 2.899 & -3.304 & 5.862 \\
\hline Wage in natural log & -2.330 & -2.525 & $-4.903^{*}$ & -2.383 & $-4.430^{*}$ \\
\hline Education and health expenditure per capita & $-0.168^{* *}$ & $-0.188^{* *}$ & -0.062 & $-0.170^{* *}$ & -0.062 \\
\hline \multicolumn{6}{|l|}{ Year } \\
\hline 1995 & $-4.447^{*}$ & $-4.433^{*}$ & (base) & $-4.480^{*}$ & (base) \\
\hline 2000 & -4.875 & -4.702 & 0.892 & -4.834 & 1.265 \\
\hline 2010 & 5.436 & 5.843 & $13.761^{* *}$ & 5.505 & $13.316^{* *}$ \\
\hline Constant & $34.234^{*}$ & $34.175^{*}$ & $39.619^{*}$ & $34.546^{*}$ & $35.699^{*}$ \\
\hline Number of observations & 120 & 120 & 92 & 120 & 92 \\
\hline Adjusted $\mathrm{R}^{2}$ & 0.535 & 0.537 & 0.514 & 0.535 & 0.515 \\
\hline
\end{tabular}

$\mathrm{FDI}=$ foreign direct investment, $\mathrm{GDP}=$ gross domestic product.

Note: ${ }^{*} p<0.05,{ }^{* *} p<0.01$.

Source: Author's calculations. 


\section{REFERENCES}

Balassa, B. 1965. "Trade Liberalisation and 'Revealed' Comparative Advantage.” The Manchester School of Economic and Social Studies 33 (2): 99-123.

Baldwin, Richard, and Javier Lopez-Gonzalez. 2013. "Supply Chain Trade: A Portrait of Global Patterns and Several Testable Hypotheses.” NBER Working Paper No. 18957.

Chan, Kam Wing. 2013. "China, Internal Migration." In The Encyclopedia of Global Migration, edited by Immanuel Ness and Peter Bellwood. Blackwell Publishing.

Ebenstein, Avraham. 2011. "Estimating a Dynamic Model of Sex Selection in China.” Demography 48 (2): 783-811. doi: 10.1007/s13524-011-0030-7

Eloot, Karel, Alan Huang, and Martin Lehnich. 2013. “A New Era for Manufacturing in China.” McKinsey Quarterly.

Qian, Nancy. 2008. "Missing Women and the Price of Tea in China: The Effect of Sex-Specific Earnings on Sex Imbalance." Quarterly Journal of Economics 123 (3): 1251-85.

Sen, Amartya. 1990. "More Than 100 Million Women Are Missing." The New York Review of Books 37 (20). 20 December.

_2003. "Missing Women—Revisited: Reduction in Female Mortality Has Been Counterbalanced by Sex Selective Abortions." British Medical Journal 327 (7427): 129799. doi:10.1136/bmj.327.7427.1297

Shepherd, Ben, and Susan Stone. 2017. "Trade and Women." ADBI Working Paper Series No. 648. Tokyo: Asian Development Bank Institute.

Wang, Limin. 2014. "Shifting the Discourse on China's Economic Growth: It Is the Quality Not the Speed of Growth That Matters." In Inclusive Growth and Development in the 21th Century: A Structural and Institutional Analysis of China and India, edited by Dilip Dutta. Singapore: World Scientific.

Wei, Shang-Jin, and Xiaobo Zhang. 2011. "The Competitive Saving Motive: Evidence from Rising Sex Ratios and Savings Rates in China.” Journal of Political Economy 119 (3): 511-64. 


\section{How Women Have Fared with the Rise of the People's Republic of China in Global Supply Chain Trade}

This paper examines the effects of the country's rapid integration into the supply chain on women's occupational status. The analysis shows global integration through trade expansion improved the concentration of men and women equally in professional and skilled occupations and in management positions but increased employment in manufacturing for global supply chain trade faster for women than men. This led to relative income gains for women, which in turn decreased the male-female sex ratio among those aged 0-4 years. Gender-specific policies like higher education and skills training for professional and leadership positions complemented with private sector incentives for female employment can promote gender equality.

\section{About the Asian Development Bank}

ADB's vision is an Asia and Pacific region free of poverty. Its mission is to help its developing member countries reduce poverty and improve the quality of life of their people. Despite the region's many successes, it remains home to a large share of the world's poor. ADB is committed to reducing poverty through inclusive economic growth, environmentally sustainable growth, and regional integration.

Based in Manila, ADB is owned by 67 members, including 48 from the region. Its main instruments for helping its developing member countries are policy dialogue, loans, equity investments, guarantees, grants, and technical assistance. 